\title{
Adapting Cities to Climate Change
}

DOI:

10.1080/09640568.2017.1355777

\section{Document Version}

Accepted author manuscript

Link to publication record in Manchester Research Explorer

\section{Citation for published version (APA):}

Carter, J., Handley, J., Butlin, T., \& Gill, S. (2017). Adapting Cities to Climate Change: Exploring the Flood Risk Management Role of Green Infrastructure Landscapes. Journal of Environmental Planning and Management. https://doi.org/10.1080/09640568.2017.1355777

\section{Published in:}

Journal of Environmental Planning and Management

\section{Citing this paper}

Please note that where the full-text provided on Manchester Research Explorer is the Author Accepted Manuscript or Proof version this may differ from the final Published version. If citing, it is advised that you check and use the publisher's definitive version.

\section{General rights}

Copyright and moral rights for the publications made accessible in the Research Explorer are retained by the authors and/or other copyright owners and it is a condition of accessing publications that users recognise and abide by the legal requirements associated with these rights.

\section{Takedown policy}

If you believe that this document breaches copyright please refer to the University of Manchester's Takedown Procedures [http://man.ac.uk/04Y6Bo] or contact uml.scholarlycommunications@manchester.ac.uk providing relevant details, so we can investigate your claim.

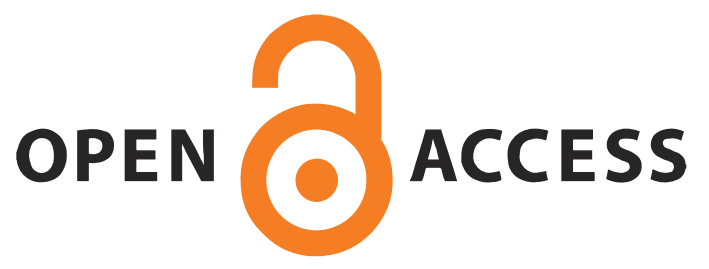




\section{Journal of Environmental 3 Routledge Planning and Management 1 Trylor b francisicroup}

\section{Adapting Cities to Climate Change - Exploring the Flood Risk Management Role of Green Infrastructure Landscapes}

\begin{tabular}{|c|l|}
\hline Journal: & Journal of Environmental Planning and Management \\
\hline Manuscript ID & CJEP-2016-0165.R1 \\
\hline Manuscript Type: & Research Article \\
\hline Keywords: & $\begin{array}{l}\text { Climate change, Climate change adaptation, Land use change, Green } \\
\text { infrastructure, Governance }\end{array}$ \\
\hline Abstract: & $\begin{array}{l}\text { There is now an emerging sense of the scope and nature of response that } \\
\text { can be implemented at building and neighbourhood scales to help adapt } \\
\text { cities and urban areas to the changing climate. In comparison, the role of } \\
\text { larger natural and semi-natural landscapes that surround and permeate } \\
\text { cities is less well understood. Addressing this knowledge gap, this paper } \\
\text { outlines two case studies that describe and map the flood risk management } \\
\text { functions offered by green infrastructure landscapes situated within the } \\
\text { Urban Mersey Basin in North West England. The case studies establish that } \\
\text { areas potentially exposed to flooding can be located at some distance, and } \\
\text { within different jurisdictions, from upstream areas where the flood hazard } \\
\text { may be generated and could be moderated via functions provided by green } \\
\text { infrastructure landscapes. This raises planning and governance challenges } \\
\text { connected to supporting and enhancing flood risk management functions } \\
\text { provide by green infrastructure landscapes. }\end{array}$ \\
\hline
\end{tabular}

\section{SCHOLARONE" \\ Manuscripts}




\title{
Adapting Cities to Climate Change - Exploring the Flood Risk Management Role of Green Infrastructure Landscapes
}

\begin{abstract}
There is now an emerging sense of the scope and nature of response that can be implemented at building and neighbourhood scales to help adapt cities and urban areas to the changing climate. In comparison, the role of larger natural and semi-natural landscapes that surround and permeate cities is less well understood. Addressing this knowledge gap, this paper outlines two case studies that describe and map the flood risk management functions offered by green infrastructure landscapes situated within the Urban Mersey Basin in North West England. The case studies establish that areas potentially exposed to flooding can be located at some distance, and within different jurisdictions, from upstream areas where the flood hazard may be generated and could be moderated via functions provided by green infrastructure landscapes. This raises planning and governance challenges connected to supporting and enhancing flood risk management functions provide by green infrastructure landscapes.
\end{abstract}

\section{Key words}

Climate change; Climate change adaptation; Land use change; Green infrastructure; Governance.

\section{Introduction}


Whilst cities and urban areas are centres of political and economic power, it is now understood that their form and function intensifies climate change impacts. Urban development and expansion results in hard surfacing and the loss of woodlands and agricultural areas, for example. This can exacerbate weather and climate hazards (Gill et al 2007). Coupled with projected increases in temperature and rainfall intensity due to climate change, there is the potential for increasing exposure of receptors in urban areas, including people, buildings and infrastructure, to hazards including heat wave and flood events. As a result, adaptation strategies and actions are needed to maintain quality of life and economic prosperity in urban areas as the climate changes.

Climate change adaptation measures should be developed at multiple interconnected spatial scales, including building, neighbourhood and conurbation scales (Shaw et al 2007). A spatially tiered adaptation approach involves complementary measures being developed at different spatial scales. Attention is often paid to adaptation at local scales, including at the level of individual buildings and developments, which is understandable given that this is where climate change impacts are often experienced. However, cities and urban areas are characterised by high levels of complexity and connectivity of their constituent land uses and infrastructures, which influences both the generation of and response to extreme weather and climate change impacts. To progress a systemic approach to climate change adaptation that recognises these features of urban systems, it is necessary to look beyond the local scale. This will involve considering the role of larger natural and semi-natural landscapes situated within and around cities and urban areas. This importance of taking a broader spatial approach is acknowledged by the European Environment Agency regarding one key hazard that provides the focus of this paper, flooding; "Flood risks in a city can be strongly influenced by factors 
outside the city boundaries such as upstream river management. It requires a regional approach for solving the urban flood problems" (EEA 2012, 35).

This paper focuses on green infrastructure. According to the European Commission (2013: 7) green infrastructure can be defined as, “...a strategically planned network of high quality natural and semi-natural areas with other environmental features, which is designed and managed to deliver a wide range of ecosystem services and protect biodiversity in both rural and urban settings." The UK Green Building Council (2015: 3) notes that green infrastructure features range in scale, “...from individual street trees, green roofs and private gardens through to parks, rivers and woodlands, transport corridors, verges and, at the larger scale, wetlands, forests and agricultural land." Green infrastructure is therefore multi-scalar. Also, green infrastructure is recognised as having the potential to play an important element in urban climate change adaptation from a general perspective (European Commission 2013; Forest Research 2010) and relating to flood risk management specifically (Armson et al 2013; Stovin et al 2008).

The focus of this paper is on green infrastructure at the landscape scale, which encompasses sometimes interconnected areas of land lying within and around cities and urban areas. At the landscape scale, green infrastructure encompasses various land uses including forests, woodlands, moorlands, agricultural land, urban green spaces such as parks, rivers and lakes. Although green infrastructure landscapes have the potential to contribute to climate change adaptation and flood risk management goals, their large scale, cross-boundary nature and the multiple sectors and stakeholders potentially involved in their ownership and management, presents notable planning and governance challenges. 
Situated within this broad context, this paper draws upon findings developed within two case studies located within the Urban Mersey Basin in Northwest England with the aim of informing future policy, practice and research related to supporting and enhancing the flood risk management functions of green infrastructure landscapes. Three specific objectives are:

- To raise awareness of the flood risk management functions provided by green infrastrucutre landscapes and to describe and map these functions within the two case study areas.

- To explore the role of green infrastructure landscapes in adapting cities to flooding under future climate change conditions, drawing on modelling work undertaken within the case studies.

- To use the case study findings as a platform to highlight planning and govenance challenges related to progressing this agenda.

The paper continues with a literature review focusing on the climate change adaptation role of green infrastructure landscapes, particularly concerning flood risk management. This is followed by a description of the research methodologies applied within the case studies reported in this paper. Two case studies based on the Urban Mersey Basin in North West England are then presented. The case studies present spatial analysis outputs that examine the flood risk management functions of green infrastructure landscapes in the Urban Mersey Basin, both in the present day and under future climate change conditions. The paper concludes with a discussion of planning and governance challenges connected to enhancing the role of landscape scale green infrastructure as an element of flood risk management strategies. 


\section{Literature review}

The value of green infrastructure as a climate change adaptation response is increasingly recognised within policy and research communities (European Commission 2013; Forest Research 2010). The adaptation benefits of green infrastructure include moderating temperatures via evaporative cooling and shading from the sun (Armson et al 2012; Bowler et al 2010; Kleerekoper et al 2012; Spronken-Smith and Oke 1998) and increasing water infiltration and interception to reduce flood risk (Armson et al 2013; Stovin et al 2008). Green infrastructure has the potential to deliver numerous other social, economic and environmental benefits (Forest Research 2010); it is a multifunctional response (Hansen and Pauleit 2014).

Adaptation to climate change should, in principle, operate at multiple interconnected spatial scales reflecting the biophysical and socio-economic systems and processes that generate climate change impacts. Although there is an emerging body of knowledge and experience of building and neighbourhood scale adaptation approaches, research, policy and practice linked to larger landscape scale climate change adaptation appear to be relatively unevolved. This gap in knowledge and experience makes the development of multi-scalar adaptation strategies that integrate landscape scale initiatives alongside more localised approaches a challenging prospect. There are examples of landscape scale adaptation, however. They including a practical assessment of the potential for the application of adaptation concepts at the landscape scale in the Sierra and Stanislaus National Forests in California (Aplet and Gallo 2012), a policy review to support biodiversity adaptation strategies at the landscape scale (Land Use Consultants 2011), and the development of a decision making framework to 
support landscape scale adaptation planning for biodiversity (Oliver et al 2012). There are also clear links to related policy agendas such as calls in the UK for "more, bigger, better and joined" approaches to the conservation of ecological networks (Lawton 2010), and water management at the river basin district scale as required by the European Water Framework Directive.

There are also practical examples of landscape scale green infrastructure actions that can act to reduce extreme weather and climate change risks to cities. They include the protection and enhancement of coastal wetlands around New Orleans to lessen the power of storm surges, and the use of strategic spatial planning measures to utilise green space networks within and around Stuttgart to facilitate cool air flow into the city (Kazmierczak and Carter 2010). Under a changing climate, these initiatives offer the potential to support adaptation to increased hurricane intensity and higher temperatures respectively.

The notion of utilising natural and semi natural green infrastructure landscapes to reduce extreme weather and climate risk in urban centres raises the issue of the transfer of adaptation functions across scales and between locations. This has been considered within the literature concerning green infrastructure and flood risk management. Interventions upstream in a river catchment, including tree planting in agricultural and urban areas, have the potential to reduce the threat of flooding downstream (Armson et al 2013; Ellis et al 2006; Jackson et al 2008), particularly concerning flash floods (van Dijk and Keenan 2007). In the UK there is growing interest in the role of tree planting (and other ecosystem based approaches including upland peat bog restoration) for flood risk management (Broadmeadow et al 2014; Nisbet and Thomas 2008; Royal Society 2014; The Wildlife Trusts, n.d). For example, in North 
Yorkshire, flood plain forestry has been used to decouple the timing of flood peaks on two streams above the town of Pickering (Nisbet et al 2011; Royal Society 2014).

It has also been established that land use change affects the hydrological balance of river catchments due to its influence over processes including evapotranspiration and rainwater interception, runoff speed and infiltration (De Roo et al 2003; Wheater and Evans 2009). Modelling work by De Roo et al (2003) demonstrates the potential effect of future land use change scenarios on flood peak discharge levels, and found that that reforestation can reduce peak discharge whereas urbanisation can increase discharge levels and hence flood risk. Land use change may therefore influence flood risk, although in some cases changes to different land cover types have been found to balance each other out with little net effect on flood risk (Fox et al 2012). Further, Wheater and Evans (2009) note that predicting the impact of rural land use change on runoff processes at local scales is challenging, and that uncertainties remain over the results of related modelling exercises. Similarly, O'Connell et al (2007) state that although land use management practices can enhance runoff locally, there is less evidence that this leads to wider downstream impacts at a catchment scale, although they do acknowledge that this effect may nevertheless still be taking place yet has not been recorded.

\section{Research methodology}

A research methodology was developed to increase understanding of the potential role of green infrastructure landscapes to the management of urban flood risk under a changing climate. The research focused on exploring three related issues within two case studies: 
- Describing and mapping flood risk management functions provided by green infrastructure landscapes.

- Identifying the spatial relationships between the green infrastructure landscapes and urban administrative boundaries.

- Assesing the implications of changes to the area covered by green infrastructure landscapes on future rainwater runoff levels incorporating climate change projections.

An initial task was to identify suitable case study locations. Locations where vulnerable receptors (e.g. people, property, infrastructure assets or natural environments) are more likely to be exposed to extreme weather and climate change hazards deserve higher priority when developing climate change adaptation responses (Carter et al 2015). Two case studies located within the Urban Mersey Basin were selected on this basis. They represent areas where there is potential for a hazard, in this case fluvial flooding was selected due to its prominence within the Urban Mersey Basin (Carter and Lawson 2011), to coincide spatially with vulnerable receptors. Taking this approach, a mixed use housing site (referred to as the Lower Irwell Valley) and an economic development site (referred to as the Mersey Multi Modal Gateway or 3MG) were identified. Further details of the case study locations are included in section 4.1, which presents the case study results.

Each case study was based around a "focus area" and a surrounding "intervention catchment”. Focus areas are sites exposed to fluvial flood risk as determined by mapping available from the Environment Agency, a public body with flood risk management responsibilities covering England and Wales. Focus areas also represent locations where the mapped fluvial flood hazard coincides with receptors that are vulnerable to flooding. The 
intervention catchment refers to the watershed around the focus area. The intervention catchment represents the area where runoff is generated, and therefore where approaches could be implemented to reduce runoff volumes reaching watercourses to lessen flood risk at the downstream focus area. The case study intervention catchments were calculated using the Ordnance Survey's Land-Form Panorama digital terrain model and hydrological modelling tools. The hydrological modelling was carried out in Esri ArcGIS. The process was as follows:

- The Fill tool was applied to the Land-Form Panorama surface to remove any sinks.

- The Flow Direction tool was applied to the result.

- The Watershed tool was used, with the flow direction raster, to calculate the intervention catchment above the focus area.

\begin{abstract}
At the next stage in the research methodology, flood risk management functions provided by green infrastructure located within the two case study intervention catchments were mapped based on land cover and soil data analysis. This approach built on previous work which mapped 18 green infrastructure types and related these to 28 related functions (including Gill et al 2007; The Mersey Forest and Ordnance Survey 2011; The Mersey Forest 2013). Five flood risk management functions were mapped within this study. Details of these functions, and the data sets used to map them, are provided below:
\end{abstract}

1. Water interception: This function concerns slowing the progress of rainwater towards watercourses by intercepting precipitation before it hits the ground, and is primarily performed by trees (Xiao and McPherson 2002). Tree location and canopy cover was estimated using the Ordnance Survey’s MasterMap Topography Layer. 
2. Water infiltration: This function involves enabling rainwater that might otherwise reach watercourses to soak into the ground. It is performed by all types of green infrastructure where soil properties allow, for example on sandier soils (Gill et al 2007), except for surface water and wetlands. Where soil properties work against this function (for example on clay soils), it is assisted where trees are present as their roots break up the soil allowing infiltration (Bartens et al 2008). For the case studies, green infrastructure (other than surface water and wetlands) that intersects with freely draining soils it is counted as performing this function. The soils data used for this analysis was Cranfield University's NATMAP soilscapes. The Ordnance Survey's MasterMap Topography Layer was used to map green infrastructure coverage.

3. Accessible water storage: This function involves storing rainwater that might otherwise reach watercourses in water bodies such as lakes or reservoirs, which could then be accessed and used for other purposes. The basis for mapping this function was the Ordnance Survey’s MasterMap Topography Layer.

4. Inaccessible water storage: This function relates to the storage of rainwater in locations where it is inaccessible for other purposes, principally within peaty soils, wetlands, woodlands and orchards. Green infrastructure other than surface water that intersects with peaty soils it is counted as performing this function. Wetlands, woodlands and orchards are also counted as performing the function. The mapping of this function utilised the Ordnance Survey's MasterMap Topography Layer and Cranfield University's NATMAP soilscapes data.

5. Flow reduction via surface roughness: The basis of this function is slowing the progress of rainwater, once it is flowing across the ground, towards watercourses. Green infrastructure with high levels of ground surface roughness, such as seminatural grasslands, heathlands, moorlands, scrublands, wetlands, woodlands and some 
orchards, perform this function (Ghavasieh et al 2006; Thomas and Nisbet 2007). For the $3 \mathrm{MG}$ case study, the types of green infrastructure listed above, apart from orchards, were counted as performing the function with a $100 \%$ likelihood, and orchards are counted as performing it with a $20 \%$ likelihood. The basis of this mapping was the Ordnance Survey’s MasterMap Topography Layer. For the Lower Irwell Valley case study, CORINE Land Cover data was used to determine the locations of semi-natural grasslands, heathlands, moorlands and scrublands. Otherwise, the method followed that used for the $3 \mathrm{MG}$ case.

Composite maps were produced to visualise the number of flood risk management functions provided by green infrastructure landscapes contained within the two case study intervention catchments. Once the maps had been produced, spatial analysis of the flood risk functions provided by green infrastructure was undertaken using Geographical Information Systems (GIS) methods in order to establish their distribution according to the administrative boundaries covering the case study areas and their surrounding hinterland areas. A spatial intersection between the administrative boundaries and the green infrastructure maps was used to perform this task. This enabled an assessment to be undertaken of the spatial relationships existing between green infrastructure landscapes within the intervention catchments that provide green infrastructure functions, the focus areas that could potentially benefit from these functions, and the administrative boundaries of public sector organisations that have a role to play in managing flood risk, and land use change, within the case study areas. 
The third aspect of the research methodology concerned assessing the implications of changes to the area covered by green infrastructure landscapes on future rainwater runoff levels. To explore this issue, the Surface Temperature and Runoff (STAR) Tools (The Mersey Forest and University of Manchester 2011), were utilised within the case studies. The STAR Tools $^{1}$ are GIS- based, and are freely available online (Cavan et al 2012). They can model surface water runoff volumes under different climatic and land use conditions, which in the Urban Mersey Basin case studies enabled the runoff implications of different green infrastructure surface cover scenarios to be tested. The surface runoff model is based on the US Soil Conservation Service approach (Soil Conservation Service 1972), which draws on theory and the results of empirical studies into precipitation runoff from many small watersheds in the US. It takes a daily rainfall amount, and then calculates how much of this rainfall will not be converted to surface runoff; this could be because this rainfall is intercepted (e.g. by plants and trees), infiltrated (e.g. into the soil), or stored (e.g. in water bodies). The remaining rainfall is converted to surface runoff.

Within the case studies, runoff data was produced for rainfall occurring on the $99^{\text {th }}$ percentile winter day, which represents the average wettest day during the winter months. This rainfall event is included as a default setting with the STAR Tools, and was selected for this purpose because it provides an indication of volumes of water that could be expected during an extreme rainfall event, where the risk of associated flooding is higher. For the assessment of future flood risk, the UK Climate Projections 2050s high greenhouse gas emissions scenario was used ${ }^{2}$. The high emissions scenario is the default setting for the STAR Tools, and reflects the high emissions pathway that the world has been on over recent decades. The UK Climate

\footnotetext{
${ }^{1}$ Further information on the STAR Tools, including details of the scope of their application and the models underpinning the Tools, can be obtained at: http://maps.merseyforest.org.uk/grabs/

${ }^{2}$ Details of the UK Climate Projections can be found at: http://ukclimateprojections.metoffice.gov.uk/
} 
Projections are probabilistic, and provide a measure of the strength of the evidence that underpins a particular climate change projection. For this research the $50 \%$ probability level, which is viewed as the central estimate, was selected as this represents the most likely outcome based on current evidence and modelling methods. The aim of this third element of the case study research was to provide an insight into how change in green infrastructure cover could influence runoff volumes under a changing climate. The STAR Tools were used to determine runoff volumes arising from the rainfall event outlined above for two contrasting future land cover scenarios, which reflected a $10 \%$ increase and $10 \%$ decrease in green infrastructure cover (from current levels) across the intervention catchments. The 10\% figure was selected as this formed the basis of previous research in this field (Gill et al 2007), in addition to being a change in cover that could feasibly occur in an urbanised area such as the Urban Mersey Basin, via development pressure or restoration strategies, over the period to 2050 . In some areas, where the green infrastructure or built cover was already greater than $90 \%$ or less than $10 \%$, it was not possible to change land cover by the entire $10 \%$ and in these cases the maximum change in cover (up to $10 \%$ ) was applied.

\section{Results: the Urban Mersey Basin case studies}

Situated in North West England, the Greater Manchester and Liverpool conurbations and their immediate hinterlands are home to around 6 million people. This area represents the UK's most significant economic area outside of London (Atlantic Gateway 2012), and is described as the Urban Mersey Basin within this paper in reference to the river that flows through it. Research looking back to the 1940's established that, across Greater Manchester, flooding has been the most prevalent extreme weather event affecting the city (Carter and Lawson 2011). Recent events include flooding in December 2016 that caused significant disruption with over 2000 homes flooded and damages to infrastructure alone estimated at 
$£ 11.5$ million (Greater Manchester Combined Authorities, 2016). Climate change projections indicate that the risk of flooding could increase in this area with a rise in winter rainfall and a greater likelihood of extreme downpours across the year (Cavan 2011). Flooding can negatively affect the quality of life of residents in addition to the achievement of plans for economic growth and employment creation. The two case studies outlined below provide insights into the potential contribution of landscape scale green infrastructure to reducing flood risk at two sites located within the Urban Mersey Basin.

The first case study focus area covers $4.7 \mathrm{~km}^{2}$ within the urban core of Salford, a local authority (local authorities are referred to as municipalities in Europe) within Greater Manchester, and is referred to as the Lower Irwell Valley (see Figure 1). It is characterised by mixed use development, and contains residential buildings and sites identified as priorities for private sector investment. Its intervention catchment, the watershed of the river Irwell (a tributary of the Mersey), covers $627 \mathrm{~km}^{2}$. Fluvial flooding has affected the Lower Irwell Valley in the past, most recently in December 2016, and Environment Agency mapping indicates that certain locations within the area are at risk of fluvial flooding. Residents in Salford are highly vulnerable to flooding relative to other locations within Greater Manchester due to demographic and social factors (Lindley et al 2011).

The second case study is focused around the Mersey Multi Modal Gateway (or 3MG) in the Liverpool city region (see Figure 1). 3MG is a global logistics hub with connections to major road, rail, air and port infrastructure. It is a key element of Northwest England's economic infrastructure. Further expansion of the site is planned including enhanced rail connections and the development of warehouse and office space. Long term plans are for the $3 \mathrm{MG}$ site to 
support up to 4000 jobs. According to Environment Agency mapping, the 3MG focus area, which covers $2.2 \mathrm{~km}^{2}$, is at risk of flooding from the River Mersey and several of its local tributaries. Its intervention catchment covers $66.1 \mathrm{~km}^{2}$.

[Figure 1 near here]

For each case study area, the flood risk management functions provided by green infrastructure landscapes are explored and the relationship between these green infrastructure landscapes and urban administrative boundaries are assessed. Finally, the implications of changes to the area covered by green infrastructure landscapes for future rainwater runoff levels are considered.

\subsection{Flood risk management functions provided by green infrastructure landscapes}

The first empirical element of the case studies concerned analysing the spatial distribution of green infrastructure according to the number of flood risk management functions that it offers (from the list of five functions outlined in section 3). Figure 2 displays results for the Lower Irwell Valley focus area and intervention catchment. This map highlights that much of the green infrastructure offering multiple flood risk management functions is located a considerable distance from the focus area, in particular around the northern and eastern fringes of the intervention catchment. Similarly, Figure 3 demonstrates a clear separation between the $3 \mathrm{MG}$ focus area and the green infrastructure within its surrounding intervention catchment that provides multiple flood risk management functions. 
[Figure 2 near here]

[Figure 3 near here]

\subsection{The spatial relationships between the green infrastructure landscapes and urban administrative boundaries}

The second element of the case study involved the analysis of spatial relationships between green infrastructure landscapes providing flood risk management functions and existing administrative boundaries. Local authority and city-region boundaries were considered to reflect the spatial footprint of the public sector bodies with responsibilities over, and the potential to influence, development and land use change in the case study areas. Table 1 indicates that around one third of green infrastructure providing flood risk management functions within the Lower Irwell Valley intervention catchment lies beyond the Greater Manchester city region boundary. Looking at the functions separately, over half of the green infrastructure performing inaccessible water storage and flow reduction functions is located beyond the Greater Manchester city region boundary. Table 2 explores this issue in the context of local authority boundaries and demonstrates that Salford, which houses the Lower Irwell Valley focus area, contains only $2.3 \%$ of the total green infrastructure providing flood risk management functions in the intervention catchment. Conversely Rossendale, which houses almost a quarter of this resource, sits at least $10 \mathrm{~km}$ from the Lower Irwell Valley focus area, outside of Greater Manchester.

[Table 1 near here] 
[Table 2 near here]

This analysis was also performed for the $3 \mathrm{MG}$ case study, but only at the local authority scale as the intervention catchment falls entirely within the Liverpool City Region boundary. This established that the majority of high functioning green infrastructure sits outside of the local authority that houses the $3 \mathrm{MG}$ focus area, Halton (see Table 3). Whilst a neighbouring authority, St Helens, contains only $5.9 \%$ of the total green infrastructure in the intervention catchment, it accounts for $65.1 \%$ of the total green infrastructure providing water infiltration functionality. This relatively small piece of land therefore plays an important role in managing flood risk to the $3 \mathrm{MG}$ site. It is apparent in this case, and also within the Lower Irwell Valley case study, that the focus area at risk of flooding benefits from green infrastructure landscapes situated in areas that lie beyond the administrative boundaries, and therefore direct area of influence, of the local authority within which it sits.

[Table 3 near here]

\subsection{Implications of changes to the area covered by green infrastructure landscapes on future rainwater runoff levels}

Given the flood risk management functions offered by green infrastructure landscapes, changing the surface area of green cover could have potentially significant downstream flooding implications. This was tested within the case study areas using the STAR Tools. 
Tables 4 and 5 provides details of STAR Tools outputs indicating rainwater runoff volumes for the Lower Irwell Valley and 3MG case studies under different climate and green infrastructure surface cover scenarios. In both cases, increasing green cover from present levels is seen to reduce runoff volumes within the intervention catchments, whereas decreasing green cover increases runoff volumes. It is notable that a greater percentage increase in runoff from the baseline value (current green infrastructure cover and 1961-1990 climate conditions) can be observed for the $3 \mathrm{MG}$ case relative to the Lower Irwell Valley case. This can be explained by differences between the two intervention catchments in terms of precipitation projections, land cover characteristics and soil types (which are the inputs to the runoff model). Further, it is also evident that in both cases, due to the increase in precipitation that is a feature of climate change projections for this area, raising green infrastructure surface cover by $10 \%$ does not bring runoff volumes back to the baseline level. This highlights that increasing green infrastructure surface cover surface area will only be part of the solution for reducing flood risk in these locations.

[Table 4 near here]

[Table 5 near here]

\section{Discussion: enhancing the flood risk management potential of green infrastructure landscapes}

The Lower Irwell Valley and 3MG case studies outlined above highlight three key issues related to the flood risk management role of green infrastructure landscapes in the Urban Mersey Basin: 
1. Developing a spatial perspective of green infrastructure landscapes and their flood risk management functionality is a useful exercise. The case studies identified that certain locations within the Urban Mersey Basin house green infrastructure landscapes which provide multiple flood risk management functions. In addition to building knowledge and awareness of green infrastructure landscapes, this spatial perspective can support the development of targeted responses to protect and enhance "high value" landscapes that provide multiple flood risk management functions.

2. Changing the surface area of green infrastructure landscapes can affect runoff volumes arising from extreme rainfall events. Modelling work undertaken within the Urban Mersey Basin case studies demonstrated that increasing surface coverage can moderate runoff levels associated with higher volume rainfall events that are projected for the future under climate change. This is due to the gain in green infrastructure cover offering functions including rainwater interception, infiltration, storage and flow reduction. This suggests that approaches targeted at increasing the surface area covered by green infrastructure landscapes could be a valuable element of wider flood risk management strategies. Notably, however, increasing surface area is not the only approach that could be taken to reduce runoff. Equally, developing existing green infrastructure landscapes to enhance their flood risk management functionality, or increasing the number of functions that they provide, could also help to achieve this outcome.

3. Although green infrastructure landscapes have the capacity to provide valuable flood risk management functions, both in the present day and in the future under climate change, the Urban Mersey Basin case studies highlight that landscapes providing these functions may be located at some distance from the downstream sites that are exposed to flooding. Further, green infrastructure landscapes that can act to moderate 
flood risk and sites that are exposed to this hazard may be situated in areas that fall under the jurisdiction of different local authorities or planning bodies. Equally, the green infrastructure landscapes themselves may cover large continuous areas that fall across more than one jurisdiction.

These issues each raise themes related to planning and governing green infrastructure landscapes to aid the achievement of flood risk management goals. Governance has been defined as, "the processes through which public and private resources are coordinated in the pursuit of collective interests" (Pierre 2011,20). In the context of this paper, the resource is green infrastructure landscapes and the reduction of flood risk is the collective interest that is being pursued. Within the climate change field, developing appropriate and effective governance approaches is seen as central to building the capacity of urban areas to develop responses to adapt to the changing climate (Adger and Vincent 2005; Bulkeley 2010; Brooks et al 2005). It is also acknowledged that adaptation is a multilevel governance challenge due to the range of sectors and integrated spatial scales that the agenda encompasses (Amundsen et al 2010, Bauer and Stenuer 2014).

The Urban Mersey Basin case studies highlight that supporting and enhancing the flood risk management functions of landscape scale green infrastructure requires planning processes and governance structures that cross administrative boundaries. In addition, these processes and structures should reflect the large spatial scales over which green infrastructure landscapes exist and related natural processes operate, for example linked to river catchment hydrology. However, planning processes and governance structures that acknowledge and respond to these characteristics of green infrastructure landscapes are not always in place for 
cities and urban areas. Drawing on a study of the Greater Stockholm Metropolitan Area, Borgstrom et al (2006) note that "scale mismatches" exist between institutional management frameworks and ecological patterns and processes. They suggest that these mismatches are particularly evident in urban areas, and act to reduce the capacity of green spaces to provide ecological services. Similarly, Cumming et al (2012) note that scale mismatches of this type can; “...reduce system resilience and force the system towards undesirable states."

Other potential challenges to enhancing and expanding green infrastructure landscapes include fragmented patterns of land ownership and the constraints this places on the development of coordinated approaches over larger areas. Also, mechanisms are needed to incentivise land owners to play a role in utilising their green infrastructure landscapes to support the achievement of downstream flood risk reduction goals. The payment for ecosystem services approach is starting to be used in this way in some areas. The UK government's Department for Environment Food and Rural Affairs describe payment for ecosystem services as, "schemes in which the beneficiaries, or users, of ecosystem services provide payment to the stewards, or providers, of ecosystem services" (Defra 2013, 13). A relevant example is the implementation of land management and woodland creation schemes to reduce flood risk in Pickering (North Yorkshire, UK) (Nisbet et al 2011).

\section{Conclusion}

Although the specific case study locations referred to in this paper will be unfamiliar to many, this research has demonstrated that green infrastructure landscapes provide valuable flood risk management functions, both in the present day and in the context of adapting to the 
changing climate. It also appears that the loss of green infrastructure cover can act to increase runoff volumes and associated flood risk. These findings are significant in the context of Urban Mersey Basin, where the case study research underpinning this paper was undertaken. Here, flooding is already a major problem and climate change is projected to raise winter rainfall volumes and increase the incidence of extreme downpours across the year, intensifying the risk of future flooding. Given that many cities and urban areas across the world are also facing interacting pressures linked to urbanisation and climate change, this paper also has a useful broader function in raising awareness of, and building the evidence base concerning, the protection and enhancement of landscape scale green infrastructure for flood risk management. It also demonstrates methods that can be applied to develop an understanding of these issues in other areas.

In mapping flood risk management functions linked to green infrastructure landscapes, the case studies were also able to establish that that these landscapes may be located at a considerable distance from downstream sites potentially exposed to flood hazards, and may often be within different jurisdictions. This raises particular planning and governance challenges. Notably, planning processes and governance structures should recognise the spatial characteristics of green infrastructure landscapes, particularly their large scale and cross boundary nature, and also facilitate collaboration between actors across administrative boundaries. Spatial plans, which manage the development and use of land, and river basin management plans produced under the European Water Framework Directive primarily to improve water quality, provide examples of planning processes that could in principle have a role to play in this context. Ultimately, developing synergies between natural systems and administrative units is necessary in order to adapt urban areas to the changing climate, and 
further research is needed to establish the extent to which this could be realised in practice and how it could be further encouraged.

Although this paper has focused at the landscape scale, it is important to emphasise that flood risk management, and adaptation to climate change more generally, requires multi-scalar and multi-sectoral approaches. A systems perspective is needed with green infrastructure landscapes positioned as part of a suite of responses that integrate across spatial scales encompassing landscapes, watersheds and river valleys down to individual streets and buildings. Increasing the coverage and quality of green infrastructure landscapes will only ever be one of a diverse range of spatially tiered approaches to reduce flood risk, although it does appear that this particular measure receives relatively little attention within policy, practice and research at present. The case studies presented within this paper go some way to address this knowledge gap, yet they only looked at two locations and one climate change adaptation function of green infrastructure landscapes, flood risk management.

Complementary research looking at green infrastructure landscapes in different locations, concerning additional adaptation functions, such as food production, cool air transfer and biodiversity conservation, and also climate change hazards including heat stress would be a useful next step. However, the reality remains that progressing climate change adaptation strategies at the landscape scale is demanding. This is particularly the case where activities relate to spaces that cross administrative boundaries, and are designed to deliver benefits to sites in different administrative areas from where the activities are implemented. Networks of responsible organisations and agencies should be encouraged to develop planning processes and governance structures that more fully reflect the scope and scale of the urban climate change adaptation challenge and the green infrastructure landscapes that can play a part in the response. 


\section{References}

- Adger, W. Neil and Katharine Vincent. 2005. "Uncertainty In Adaptive Capacity". Comptes Rendus Geoscience 337 (4): 399-410. doi:10.1016/j.crte.2004.11.004.

- Amundsen, H., Berglund, F., and Westskog, H. 2010. Overcoming Barriers to Climate Change Adaptation-A Question of Multilevel Governance? Environment and Planning C. 28 (2): 276-289.

- Aplet, Greg., and John Gallo. 2011. Applying Climate Adaptation Concepts to the Landscape Scale: Examples from the Sierra and Stanislaus National Forests. Washington DC: The Wilderness Society.

- Armson, D., P. Stringer, and A.R. Ennos. 2012. "The Effect Of Tree Shade And Grass On Surface And Globe Temperatures In An Urban Area". Urban Forestry \& Urban Greening 11 (3): 245-255. doi:10.1016/j.ufug.2012.05.002.

- Armson, D., P. Stringer, and A.R. Ennos. 2013. "The Effect Of Street Trees And Amenity Grass On Urban Surface Water Runoff In Manchester, UK". Urban Forestry \& Urban Greening 12 (3): 282-286. doi:10.1016/j.ufug.2013.04.001.

- Atlantic Gateway. 2012. Atlantic Gateway Business Plan. Warrington: Atlantic Gateway.

- Bartens, Julia, Susan D. Day, J. Roger Harris, Joseph E. Dove, and Theresa M. Wynn. 2008. "Can Urban Tree Roots Improve Infiltration Through Compacted Subsoils For Stormwater Management?". Journal Of Environment Quality 37 (6): 2048. doi:10.2134/jeq2008.0117.

- Bauer, A and Stenuer, R. 2014. Multi-level governance of climate change adaptation through regional partnerships in Canada and England. Geoforum 51: 121-129. 
- Borgstrom, Sara., Thomas Elmqvist, Per Angelstam, and Christine Alfsen-Norodom. 2006. "Scale Mismatches in Management of Urban Landscapes". Ecology and Society $11(2): 16$.

- Bowler, Diana E., Lisette Buyung-Ali, Teri M. Knight, and Andrew S. Pullin. 2010. "Urban Greening To Cool Towns And Cities: A Systematic Review Of The Empirical Evidence". Landscape And Urban Planning $97 \quad$ (3): 147-155. doi:10.1016/j.landurbplan.2010.05.006.

- Broadmeadow, Samantha., and Thomas Nisbet. 2014. Opportunity mapping for woodland creation to reduce diffiuse water pollution and flood risk in England and Wales. Farnham: Forest Research.

- Brooks, Nick, W. Neil Adger, and P. Mick Kelly. 2005. "The Determinants Of Vulnerability And Adaptive Capacity At The National Level And The Implications For Adaptation". Global Environmental Change 15 (2): 151-163. doi:10.1016/j.gloenvcha.2004.12.006.

- Bulkeley, Harriet. 2010. "Cities And The Governing Of Climate Change". Annual Review Of Environment And Resources 35 (1): 229-253. doi:10.1146/annurevenviron-072809-101747.

- Carter, Jeremy G., Gina Cavan, Angela Connelly, Simon Guy, John Handley, and Aleksandra Kazmierczak. 2015. "Climate Change And The City: Building Capacity For Urban Adaptation". Progress In Planning 95: 1-66. doi:10.1016/j.progress.2013.08.001.

- Carter, Jeremy G., and Nigel Lawson. 2011. Looking back and projecting forwards: Greater Manchester's weather and climate. Manchester: The University of Manchester. 
- Cavan, Gina. 2011. Climate projections for Greater Manchester. Manchester: The University of Manchester.

- Cavan, Gina., Tom Butlin., Susannah Gill., Richard Kingston, and Sarah Lindley.

2012. Web-GIS tools for climate change adaptation planning in cities. In Handbook of Climate Change Adaptation. Berlin: Springer-Verlag.

- Cumming, Graeme S., Per Olsson, F. S. Chapin, and C. S. Holling. 2012. "Resilience, Experimentation, And Scale Mismatches In Social-Ecological Landscapes".

Landscape Ecology 28 (6): 1139-1150. doi:10.1007/s10980-012-9725-4.

- Defra (Department for Enviroment Food and Rural Affairs). 2013. Payment for Ecosystem Services: a Best Practice Guide. London: Defra.

- De Roo, Ad, Guido Schmuck, Vanda Perdigao, and Jutta Thielen. 2003. "The Influence Of Historic Land Use Changes And Future Planned Land Use Scenarios On Floods In The Oder Catchment". Physics And Chemistry Of The Earth, Parts A/B/C 28 (33-36): 1291-1300. doi:10.1016/j.pce.2003.09.005.

- Ellis, T. W., S. Leguédois, P. B. Hairsine, and D. J. Tongway. 2006. "Capture Of Overland Flow By A Tree Belt On A Pastured Hillslope In South-Eastern Australia". Aust. J. Soil Res. 44 (2): 117. doi:10.1071/sr05130.

- EEA (European Environment Agency). 2012. Urban adaptation to climate change in Europe: Challenges and opportunities for cities together with supportive national and European policies. EEA report, no. 2/2012. Luxembourg: Office for Official Publications of the European Union.

- European Commission. 2013. Building a Green Infrastructure for Europe. European Commission, Brussels.

- Forest Research. 2010. Benefits of green infrastructure. Farnham: Forest Research. 
- Fox, Dennis M., Emmanuelle Witz, Violaine Blanc, Cécile Soulié, Marc PenalverNavarro, and Alain Dervieux. 2012. "A Case Study Of Land Cover Change (19502003) And Runoff In A Mediterranean Catchment". Applied Geography 32 (2): 810821. doi:10.1016/j.apgeog.2011.07.007.

- Ghavasieh, Ahmad-Reza, Christine Poulard, and André Paquier. 2006. "Effect Of Roughened Strips On Flood Propagation: Assessment On Representative Virtual Cases And Validation". Journal Of Hydrology 318 (1-4): 121-137. doi:10.1016/j.jhydrol.2005.06.009.

- Gill, S.E, J.F Handley, A.R Ennos, and S Pauleit. 2007. "Adapting Cities For Climate Change: The Role Of The Green Infrastructure". Built Environ 33 (1): 115-133. doi:10.2148/benv.33.1.115.

- Greater Manchester Combined Authorities. 2016. Flood Investigation Report Greater Manchester 26 December 2016. Greater Manchester Combined Authorities, Manchester.

- Hansen, R. and Pauleit, S. 2014. From multifunctionality to multiple ecosystem services? A conceptual framework for multifunctionality in green infrastructure planning for urban areas. AMBIO: A Journal of the Human Environment 43:516-529. DOI 10.1007/s13280-014-0510-2.

- Jackson, B.M., H.S. Wheater, N.R. Mcintyre, J. Chell, O.J. Francis, Z. Frogbrook, M. Marshall, B. Reynolds, and I. Solloway. 2008. "The Impact Of Upland Land Management On Flooding: Insights From A Multiscale Experimental And Modelling Programme". Journal Of Flood Risk Management 1 (2): 71-80. doi:10.1111/j.1753318x.2008.00009.x. 
- Kazmierczak, Aleksandra., and Jeremy G Carter. 2010. Adaptation to climate change using green and blue infrastructure: A database of case studies. Manchester: The University of Manchester.

- Kleerekoper, Laura, Marjolein van Esch, and Tadeo Baldiri Salcedo. 2012. "How To Make A City Climate-Proof, Addressing The Urban Heat Island Effect". Resources, Conservation And Recycling 64: 30-38. doi:10.1016/j.resconrec.2011.06.004.

- Land Use Consultants. 2011. Developing Adaptive Landscapes: Helping biodiversity adapt to climate change. London: Land Use Consultants.

- Lawton, John. 2010. Making space for nature: a review of Englands wildlife sites and nature conservation. London: Defra.

- Lindley, Sarah., John O’Neill., Joseph Kandeh., Nigel Lawson., Richard Christian., and Martin O’Neill. 2011. Climate change, justice and vulnerability. York: Joseph Rowntree Foundation.

- Nisbet, Thomas., and Huw Thomas. 2008. Restoring Floodplain Woodland for Flood Aleviation. London: Defra.

- Nisbet, Thomas, Simon Marrington., Huw Thomas., Samantha Broadmedow., and Gregory Valatin. 2011. Slowing the flow at Pickering. London: Defra.

- O’Connell, P. E., J. Ewen, G. O’Donnell, and P. Quinn. 2007. "Is There A Link Between Agricultural Land-Use Management And Flooding?". Hydrol. Earth Syst. Sci. 11 (1): 96-107. doi:10.5194/hess-11-96-2007.

- Oliver, Tom H., Richard J. Smithers, Sallie Bailey, Clive A. Walmsley, and Kevin Watts. 2012. "A Decision Framework For Considering Climate Change Adaptation In Biodiversity Conservation Planning". J Appl Ecol 49 (6): 1247-1255. doi:10.1111/1365-2664.12003. 
- Pierre, Jon. 2011. The Politics of Urban Governance. Basingstoke: Palgrave Macmillan.

- Royal Society. 2014. Resilience to Extreme Weather. London: Royal Society.

- Shaw, Robert., Michelle Colley., and Richandra Connell. 2007. Climate change adaptation by design: a guide for sustainable communities. London: Town and Country Planning Association.

- Spronken-Smith, R. A. and T. R. Oke. 1998. "The Thermal Regime Of Urban Parks In Two Cities With Different Summer Climates". International Journal Of Remote Sensing 19 (11): 2085-2104. doi:10.1080/014311698214884.

- Soil Conservation Service. 1972. Soil Conservation Service National Engineering Handbook - Section 4: Hydrology. Washington DC: United States Department of Agriculture, Soil Conservation Service.

- Stovin, V. R., A. Jorgensen, and A. Clayden. 2008. "Street Trees and Stormwater Management". Arboricultural Journal $30 \quad$ (4): 297-310. doi:10.1080/03071375.2008.9747509.

- The Mersey Forest and Ordnance Survey. 2011. The value of mapping green infrastructure. London: RICS.

- The Mersey Forest and The University of Manchester . 2011. STAR tools: surface temperature and runoff tools for assessing the potential of green infrastructure in adapting urban areas to climate change. Part of the EU Interreg IVC GRaBS project. www.ginw.co.uk/climatechange.

- The Mersey Forest. 2013. Liverpool City Region and Warrington Green Infrastructure Framework. Birchwood: The Mersey Forest.

- The UK Green Building Council. 2015. Demystifying Green Infrastructure. UK Green Building Council. London. 
- The Wildlife Trusts (n.d) Invest in the Pumlumon Project. Welshpool: Montgomeryshire Wildlife Trust.

- Thomas, H. and T. R. Nisbet. 2007. "An Assessment Of The Impact Of Floodplain Woodland On Flood Flows". Water And Environment Journal 21 (2): 114-126. doi:10.1111/j.1747-6593.2006.00056.x.

- van Dijk, Albert I.J.M. and Rodney J. Keenan. 2007. "Planted Forests And Water In Perspective". Forest Ecology And Management 251 (1-2): 1-9. doi:10.1016/j.foreco.2007.06.010.

- Wheater, Howard and Edward Evans. 2009. "Land Use, Water Management And Future Flood Risk". Land Use Policy 26: S251-S264. doi:10.1016/j.landusepol.2009.08.019.

- Xiao, Qingfu and E. Gregory McPherson. “Rainfall Interception by Santa Monica’s Municipal Urban Forest.” Urban Ecosystems 6, no. 4 (December 2002): 291-302. doi:10.1023/b:ueco.0000004828.05143.67. 
2

3

4

5

6

7

8

9

10

11

12

13

14

15

16

17

18

19

20

21

22

23

24

25

26

27

28

29

30

31

32

33

34

35

36

37

38

39

40

41

42

43

44

45

46

47

48

49

50

51

52

53

54

55

56

57

58

59

60

Table 1: Distribution of green infrastructure (GI) and related flood risk management functions in the Lower Irwell Valley intervention catchment within and beyond Greater Manchester's (GM) boundaries.

\begin{tabular}{|l|l|l|l|l|l|l|}
\hline & $\begin{array}{l}\text { \% of total } \\
\text { GI in the } \\
\text { catchment }\end{array}$ & \multicolumn{3}{|c|}{$\%$ of total GI in the catchment providing flood risk management functions } \\
\cline { 3 - 7 } & $\begin{array}{l}\text { Water } \\
\text { interception }\end{array}$ & $\begin{array}{l}\text { Water } \\
\text { infiltration }\end{array}$ & $\begin{array}{l}\text { Accessible } \\
\text { water } \\
\text { storage }\end{array}$ & $\begin{array}{l}\text { Inaccessible } \\
\text { water } \\
\text { storage }\end{array}$ & $\begin{array}{l}\text { Flow } \\
\text { reduction via } \\
\text { surface } \\
\text { roughness }\end{array}$ \\
\hline Within GM & 64.7 & 64.6 & 67.2 & 67.8 & 41.0 & 42.4 \\
\hline Beyond GM & 35.3 & 35.4 & 32.8 & 32.2 & 59.0 & 57.6 \\
\hline
\end{tabular}


Table 2: Distribution of green infrastructure (GI) and related flood risk management functions across local authorities in the Lower Irwell Valley intervention catchment. (A small fragment of two other local authorities, Chorley and Hyndburn, are within the intervention catchment. They contain a small amount of GI, yet this is less than $0.1 \%$ of the total and hence these authorities are not included.) GM indicates an authority in Greater Manchester.

\begin{tabular}{|c|c|c|c|c|c|c|}
\hline \multirow{2}{*}{$\begin{array}{l}\text { Local } \\
\text { Authority }\end{array}$} & \multirow{2}{*}{$\begin{array}{l}\text { \% of total } \\
\text { GI in the } \\
\text { catchment }\end{array}$} & \multicolumn{5}{|c|}{$\%$ of total GI in the catchment providing flood risk management functions } \\
\hline & & $\begin{array}{l}\text { Water } \\
\text { interception }\end{array}$ & $\begin{array}{l}\text { Water } \\
\text { infiltration }\end{array}$ & $\begin{array}{l}\text { Accessible } \\
\text { water } \\
\text { storage }\end{array}$ & $\begin{array}{l}\text { Inaccessible } \\
\text { water } \\
\text { storage }\end{array}$ & $\begin{array}{l}\text { Flow } \\
\text { reduction via } \\
\text { surface } \\
\text { roughness }\end{array}$ \\
\hline $\begin{array}{l}\text { Blackburn } \\
\text { with } \\
\text { Darwen }\end{array}$ & 10.2 & 17.1 & 4.7 & 16.8 & 20.4 & 19.7 \\
\hline $\begin{array}{l}\text { Bolton } \\
\text { (GM) }\end{array}$ & 14.0 & 19.1 & 9.3 & 12.9 & 8.8 & 6.4 \\
\hline Burnley & 1.5 & 1.5 & 0.5 & 2.2 & 3.1 & 4.1 \\
\hline Bury (GM) & 15.3 & 16.1 & 15.0 & 17.9 & 5.9 & 6.3 \\
\hline Calderdale & 0.1 & 0.0 & 0.0 & 0.0 & 0.2 & 0.2 \\
\hline $\begin{array}{l}\text { Manchester } \\
(\mathrm{GM})\end{array}$ & 2.7 & 4.7 & 1.6 & 2.9 & 0.8 & 1.0 \\
\hline $\begin{array}{l}\begin{array}{l}\text { Oldham } \\
\text { (GM) }\end{array} \\
\end{array}$ & 5.4 & 4.0 & 6.9 & 1.2 & 2.5 & 2.2 \\
\hline $\begin{array}{l}\text { Rochdale } \\
\text { (GM) }\end{array}$ & 25.0 & 16.7 & 31.0 & 28.8 & 22.3 & 25.8 \\
\hline Rossendale & 23.5 & 16.8 & 27.5 & 13.2 & 35.3 & 33.5 \\
\hline $\begin{array}{l}\text { Salford } \\
(\mathrm{GM})\end{array}$ & 2.3 & 4.0 & 3.4 & 4.0 & 0.8 & 0.8 \\
\hline
\end{tabular}


Table 3: Distribution of green infrastructure (GI) and related flood risk management functions across local authorities in the $3 \mathrm{MG}$ intervention catchment.

\begin{tabular}{|c|c|c|c|c|c|c|}
\hline \multirow{2}{*}{$\begin{array}{l}\text { Local } \\
\text { Authority }\end{array}$} & \multirow{2}{*}{$\begin{array}{l}\text { \% of total } \\
\text { GI in the } \\
\text { catchment }\end{array}$} & \multicolumn{5}{|c|}{$\%$ of total GI in the catchment providing flood risk management functions } \\
\hline & & $\begin{array}{l}\text { Water } \\
\text { interception }\end{array}$ & $\begin{array}{l}\text { Water } \\
\text { infiltration }\end{array}$ & $\begin{array}{l}\text { Accessible } \\
\text { water } \\
\text { storage }\end{array}$ & $\begin{array}{l}\text { Inaccessible } \\
\text { water } \\
\text { storage }\end{array}$ & $\begin{array}{l}\text { Flow } \\
\text { reduction via } \\
\text { surface } \\
\text { roughness }\end{array}$ \\
\hline Halton & 13.6 & 9.6 & 0.0 & 6.7 & 3.9 & 10.1 \\
\hline Knowsley & 64.6 & 68.0 & 34.9 & 83.1 & 55.3 & 72.7 \\
\hline Liverpool & 16.0 & 16.9 & 0.0 & 2.9 & 9.1 & 10.3 \\
\hline St Helens & 5.9 & 5.6 & 65.1 & 7.3 & 31.7 & 6.9 \\
\hline
\end{tabular}


Table 4: $99^{\text {th }}$ percentile daily winter surface runoff volumes for the Lower Irwell Valley intervention catchment.

\begin{tabular}{|l|l|l|l|}
\hline Land cover & Climate change scenario & Runoff volumes & $\begin{array}{l}\text { \% change in runoff } \\
\text { volume from baseline }\end{array}$ \\
\hline Present land cover & $1961-1990$ & $14,233,625 \mathrm{~m}^{3}$ & NA \\
\hline Present land cover & $\begin{array}{l}\text { 2050s high emissions scenario } \\
50 \% \text { probability level }\end{array}$ & $15,578,219 \mathrm{~m}^{3}$ & $+9.4 \%$ \\
\hline$+10 \%$ green cover & $\begin{array}{l}\text { 2050s high emissions scenario } \\
50 \% \text { probability level }\end{array}$ & $15,074,192 \mathrm{~m}^{3}$ & $+5.9 \%$ \\
\hline$-10 \%$ green cover & $\begin{array}{l}\text { 2050s high emissions scenario } \\
50 \% \text { probability level }\end{array}$ & $16,129,503 \mathrm{~m}^{3}$ & $+13.3 \%$ \\
\hline
\end{tabular}


1

2

3

4

5

6

7

8

9

10

11

12

13

14

15

16

17

18

19

20

21

22

23

24

25

26

27

28

29

30

31

32

33

34

35

36

37

38

39

40

41

42

43

44

45

46

47

48

49

50

51

52

53

54

55

56

57

58

59

60

Table 5: $99^{\text {th }}$ percentile daily winter surface runoff volumes for the $3 \mathrm{MG}$ intervention catchment.

\begin{tabular}{|l|l|r|l|}
\hline Land cover & Climate change scenario & Runoff volumes & $\begin{array}{l}\% \text { change in runoff } \\
\text { volume from baseline }\end{array}$ \\
\hline Present land cover & $1961-1990$ & $790,087 \mathrm{~m}^{3}$ & NA \\
\hline Present land cover & $\begin{array}{l}\text { 2050s high emissions scenario } \\
50 \% \text { probability level }\end{array}$ & $980,044 \mathrm{~m}^{3}$ & $+24.0 \%$ \\
\hline$+10 \%$ green cover & $\begin{array}{l}\text { 2050s high emissions scenario } \\
50 \% \text { probability level }\end{array}$ & $939,320 \mathrm{~m}^{3}$ & $+18.9 \%$ \\
\hline$-10 \%$ green cover & $\begin{array}{l}\text { 2050s high emissions scenario } \\
50 \% \text { probability level }\end{array}$ & $1,019,157 \mathrm{~m}^{3}$ & $+29.0 \%$ \\
\hline
\end{tabular}


Figure 1: The Lower Irwell Valley and 3MG focus areas and intervention catchments.

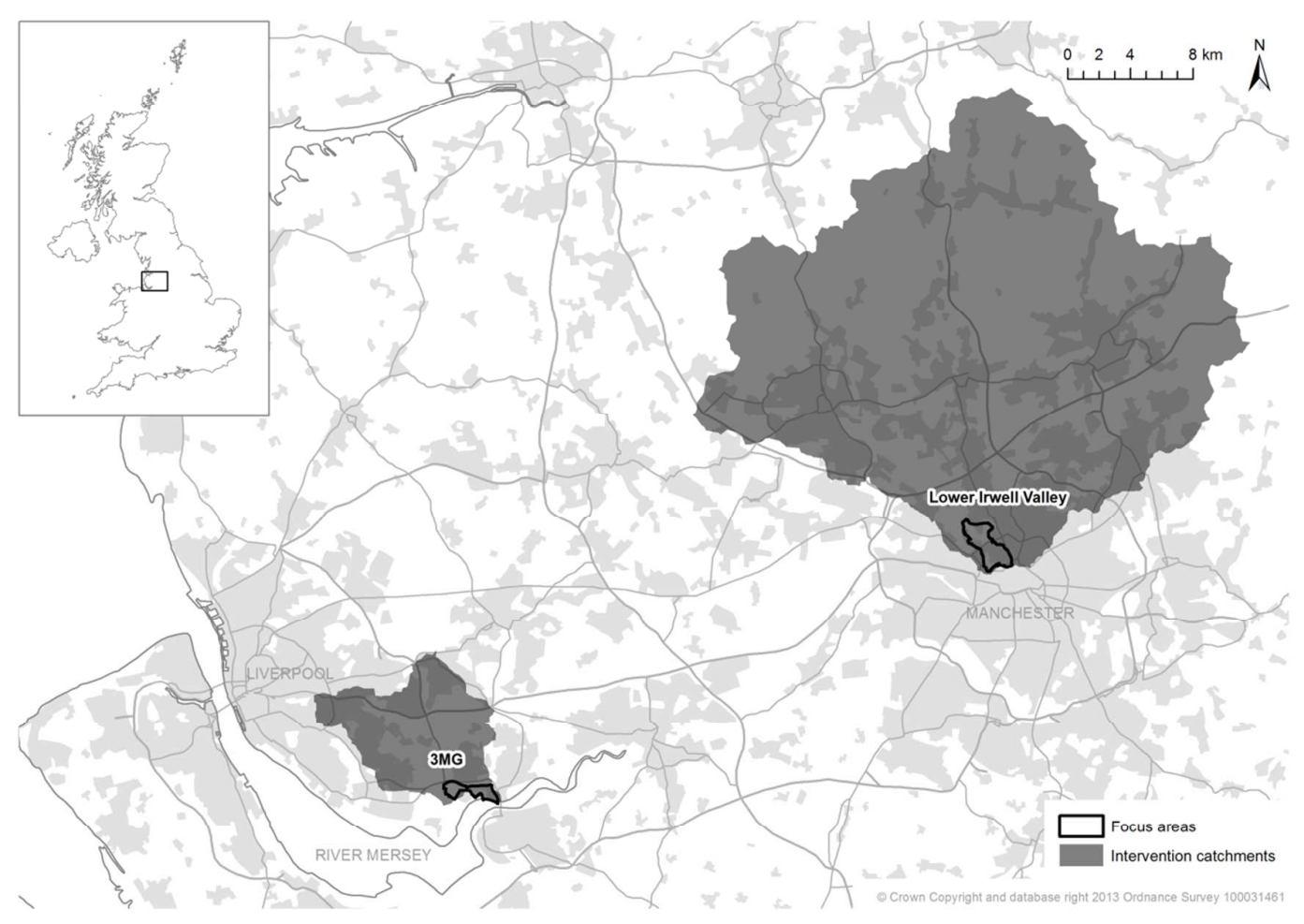

URL: http://mc.manuscriptcentral.com/cjep Email: Sarah.Cherrill2@newcastle.ac.uk 
Figure 2: Number of flood risk management functions provided by existing green infrastructure within the Lower Irwell Valley focus area and intervention catchment.

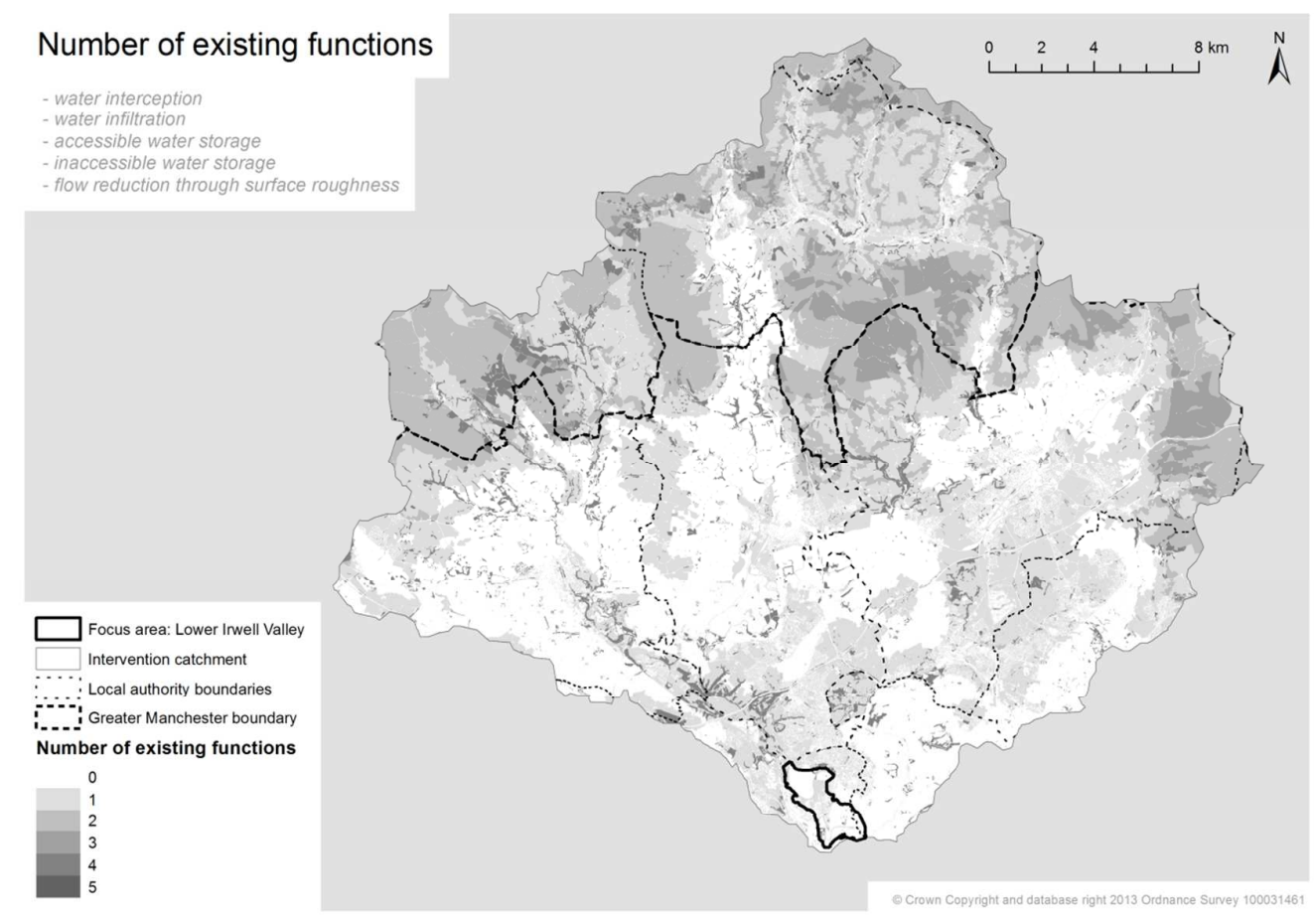


Figure 3: Number of flood risk management functions provided by existing green infrastructure within the $3 \mathrm{MG}$ focus area and intervention catchment.

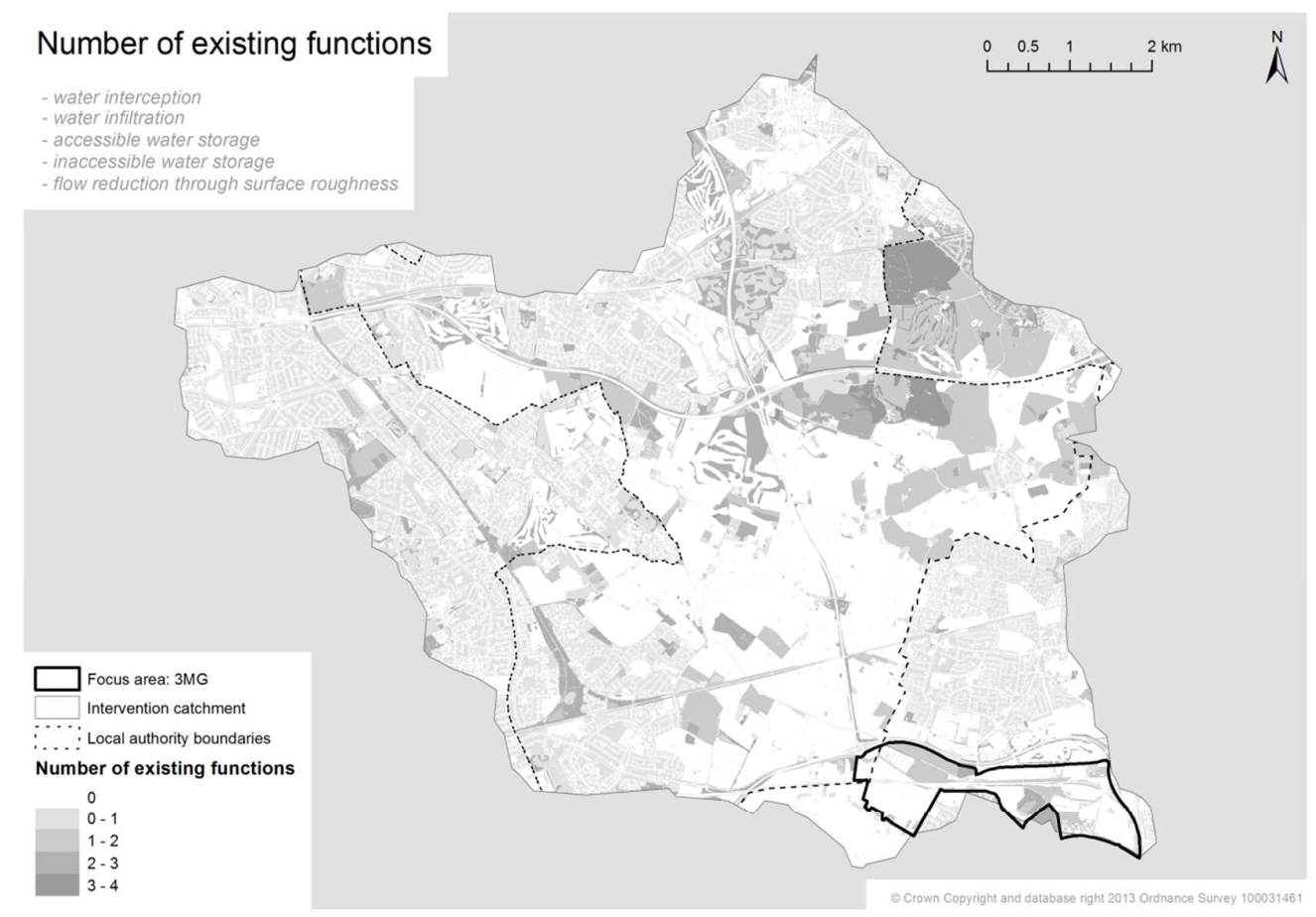




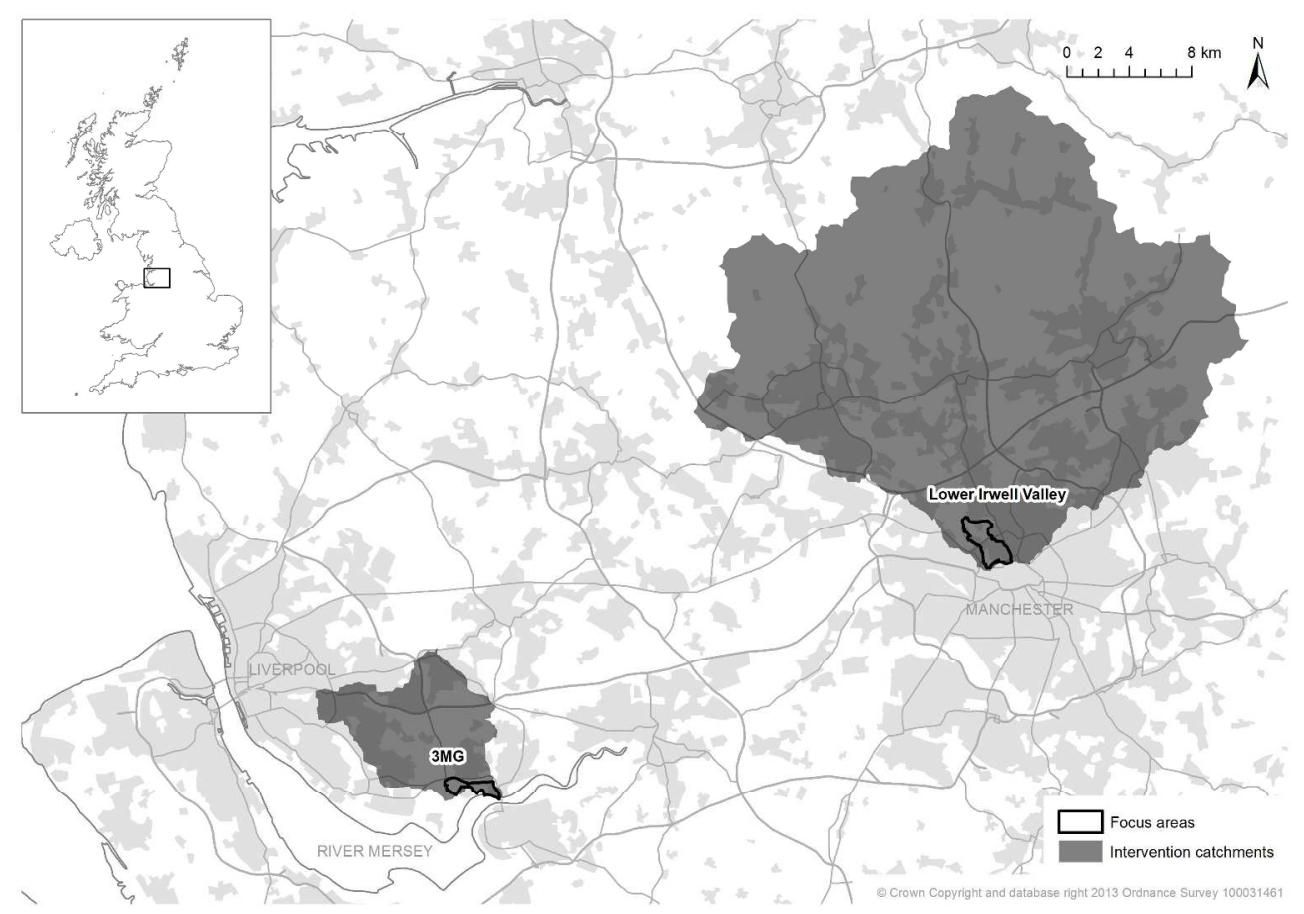

$296 \times 210 \mathrm{~mm}(300 \times 300$ DPI $)$ 


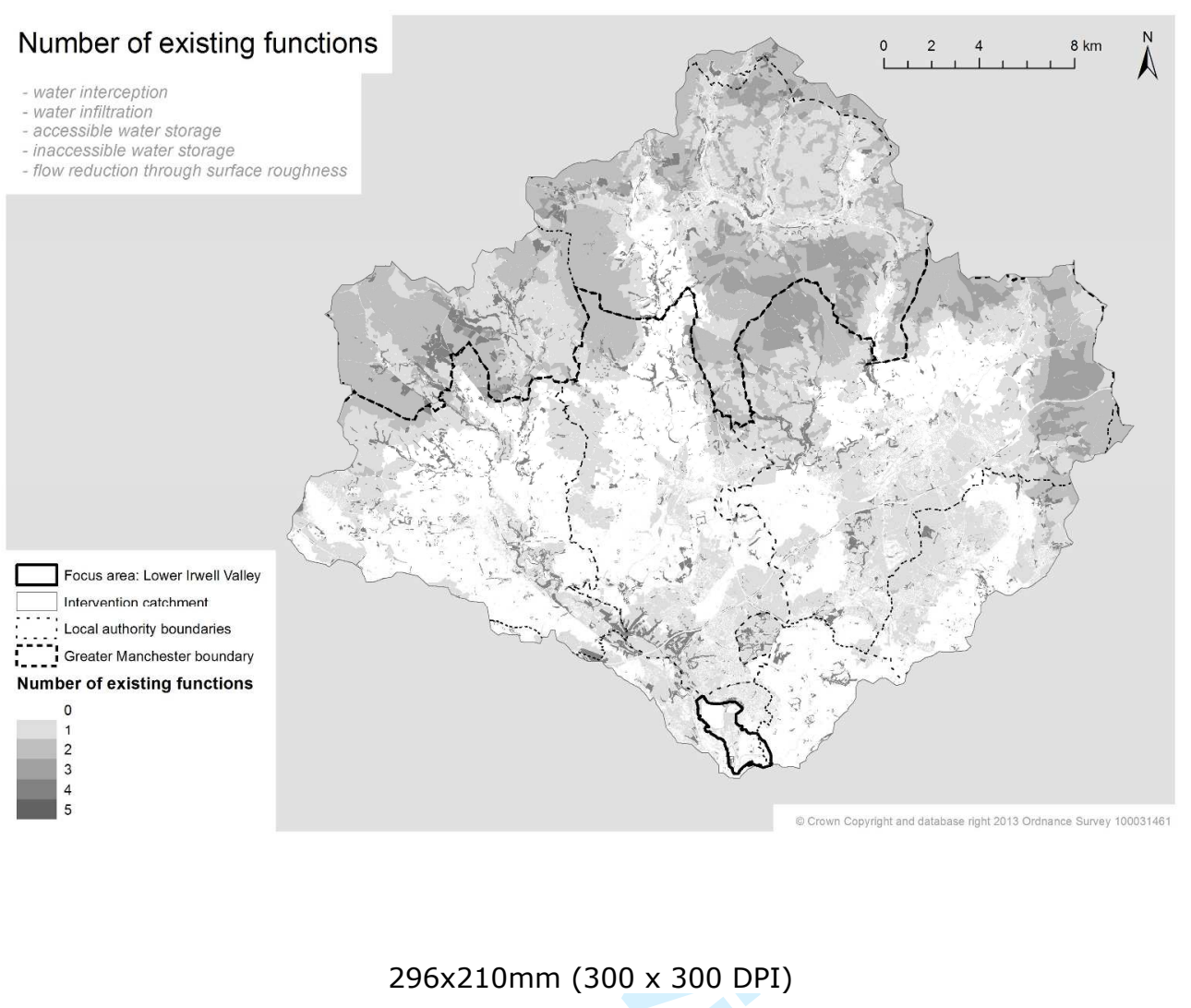

URL: http://mc.manuscriptcentral.com/cjep Email: Sarah.Cherrill2@newcastle.ac.uk 


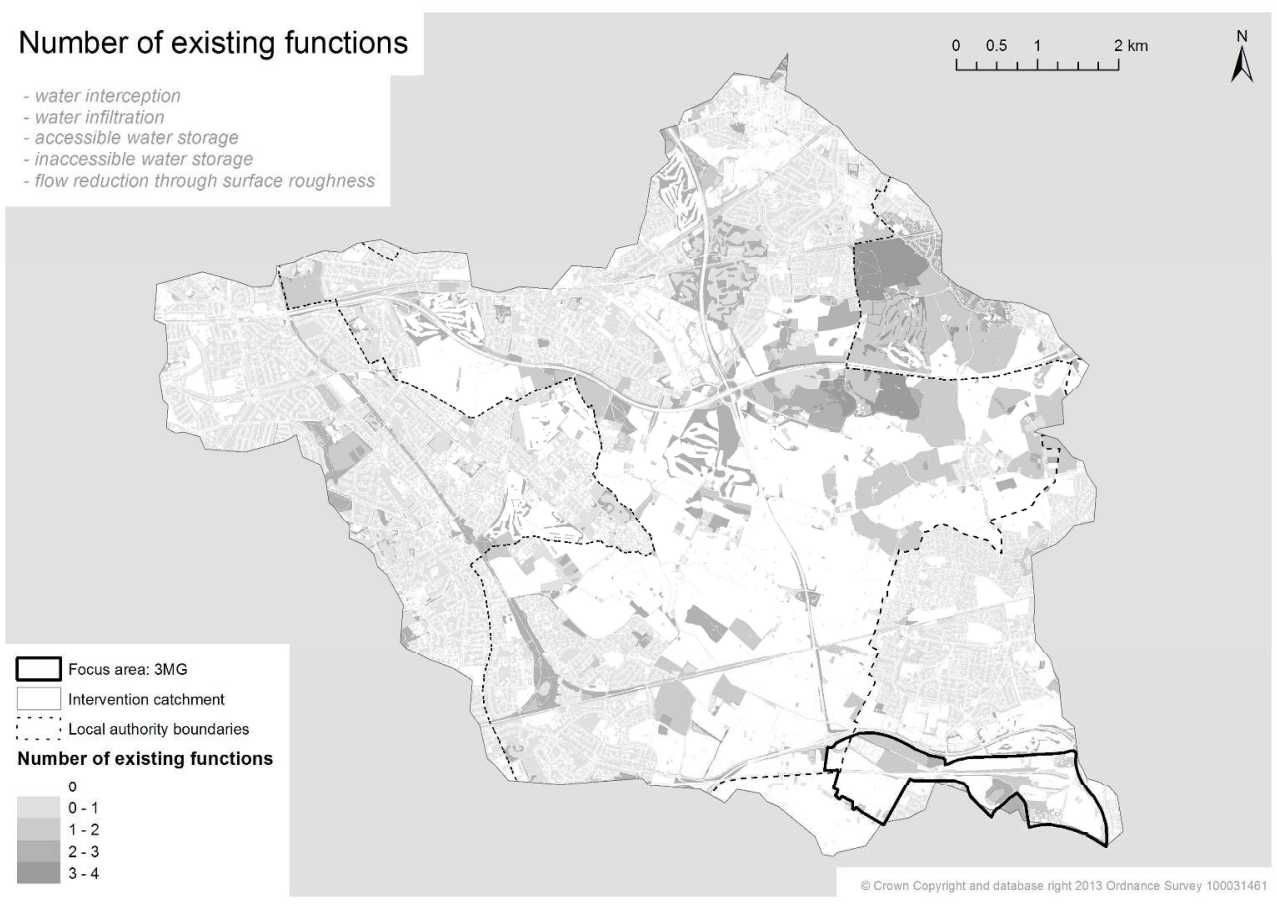

$296 \times 210 \mathrm{~mm}(300 \times 300 \mathrm{DPI})$ 